\title{
The Influence of Leadership, Motivation and Work Culture on the Performance of Poverty Reduction Program in the Administrative City of North Jakarta
}

\author{
Saut Fernando Aritonang ${ }^{1}$; Sadu Wasistiono²; Musa Hubeis ${ }^{3}$; Dewi Sulistyani ${ }^{4}$ \\ ${ }^{1}$ Doctorate Program on Management Science in Government, Universitas Satyagama Jakarta, Indonesia \\ ${ }^{2}$ Professor of IPDN, Bandung, Indonesia \\ ${ }^{3}$ Professor of Industrial Management, Bogor Agricultural University, Indonesia \\ ${ }^{4}$ Senior Lecturer, University of Satyagama, Jakarta, Indonesia \\ http://dx.doi.org/10.18415/ijmmu.v8i12.3267
}

\begin{abstract}
This study aims to analyze how much the influence of leadership, motivation and work culture on the performance of the Poverty Reduction Program in the Administrative City of North Jakarta. The research location is in North Jakarta City, DKI Jakarta Province. The selection of location is based on the assumption that the difference in status has an impact on the leadership under it vertically.The research method uses a quantitative approach with a total population of $1,724,161$ people. The sampling technique was proportional stratified random sampling using the Slovin formula, with a total of 95 samples. The data analysis technique in the research that will be carried out is simple linear regression and multiple linear regression to analyze the variables studied. The results of the study prove that leadership has an effect on $14.1 \%$, motivation has an effect on $50.2 \%$, work culture has an effect on $48.8 \%$, leadership, motivation and work culture have an effect on $50.4 \%$ of poverty in North Jakarta simultaneously . Recommendations from this research, (1) the importance of transformational leadership supported by managerial progress, education and commitment, (2) the importance of motivation both internally and externally, supported by rewards and punishments, (3) the need for a commitment so that the work culture is stronger so that it will have a positive impact on the implementation of the program to become more optimal, (4) the importance of commitment, management and availability of human resources potential, according to the needs and placements in accordance with their fields.
\end{abstract}

Keywords: Leadership; Motivation; Work Culture; Performance and Poverty

\section{Introduction}

The current era of globalization requires private and government organizations to have short-, medium- and long-term goals to be achieved through their work programs, with human resources (HR) as a driving tool to achieve goals. In organizations, leadership is a very important factor. Leadership 
encourages the emergence of motivation as a driving force for others to do something in achieving goals (Mangkunegara, 2001; 23).

The Unitary State of the Republic of Indonesia (NKRI) has a chain of government leadership levels that are more specific according to the area they lead, starting from the Lurah (Village Head), Camat (Subdistrict Head), Regent/Mayor, Governor to the President. Davis in Yuli (2005:167) defines leadership as the ability to persuade others to achieve the goals that have been set enthusiastically. According to Viethzal Rivai (2010:128-131) leadership is an activity of influencing and moving subordinates to achieve goals. In addition to having qualities and characteristics, it is also required to be able to influence and direct subordinates, leadership is defined as the skill or ability of a person to influence others to be willing to cooperate in carrying out tasks in achieving predetermined organizational goals.

In the context of Indonesia, this country needs a national leadership capable of bringing the nation and state to a common national goal as stated in the Preamble to the 1945 Constitution, namely protecting the entire Indonesian nation and the entire homeland of Indonesia, advancing public welfare, educating the nation's life and participating in carrying out order. world.

Achievement motivation means that individuals have potential energy reserves. How this energy is released and developed depends on the strength or motivation of the individual and the available situations and opportunities (McClelland in Robbins, 2001:173). Motivation plays an important role in work, so a highly motivated person will try to carry out his duties with all his might, so that his work is successful according to his abilities and it is easier to achieve success.

Work culture is derived from organizational culture. At the organizational level, the work culture provided by the organization is able to influence various variables related to processes carried out by individuals, groups and organizations (Robbins \& Judge, 2013). Organizational culture as a system of shared meaning held by members that distinguishes the organization from other organizations (Robbins, 2008: 248). Triguno $(2001 ; 13)$, argues that Work Culture is a philosophy based on a view of life as values that become the nature, habits, and driving forces, entrenched in the life of a community group or organization which is reflected in attitudes into behaviors, beliefs, ideals, opinions and actions that are realized as work.

Work culture of government is increasingly being discussed along with the challenges of the industrial revolution 4.0 which demands changes in the quality of human resources. One interesting material is the idea of implementing merit systems. Poverty is a world problem, although economic growth is one way to alleviate poverty, but high economic growth does not necessarily reduce the level of poverty, the number of poor people in a country. Supriatna (1997: 90), poverty is a completely limited situation that occurs not at the will of the person concerned. A population is said to be poor if it is characterized by low levels of education, work productivity, income, health and nutrition and welfare of life, which indicates a circle of powerlessness. Poverty can be caused by limited existing human resources, both through formal and non-formal education which in turn has consequences for the low level of informal education. 


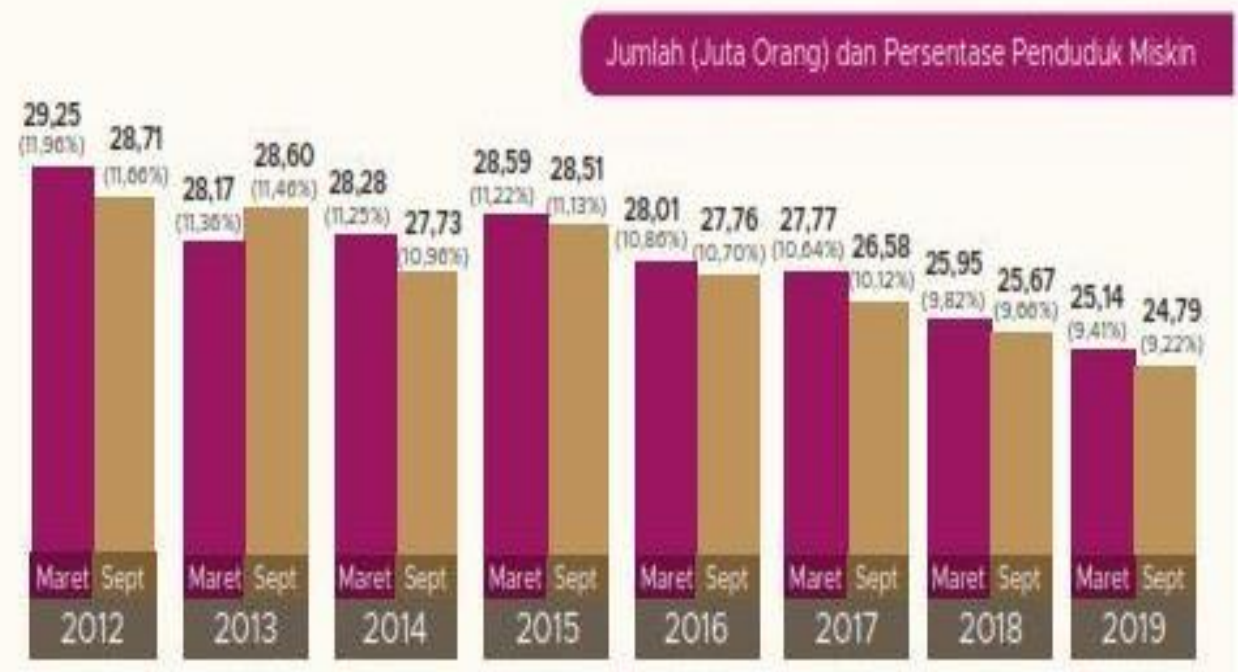

Source: BPS, September 2019

Figure 1. Poverty Profile in Indonesia in 2019

Based on Figure 1. It is clear that poverty in Indonesia is $9.22 \%$, out of a total population of 24.79 million people, a decrease of 0.26 million or $0.19 \%$ from March 2019. This is due to low inflation and food prices in Indonesia such as: rice, meat, chicken, eggs and mackerel.

Table1. Number of Poor Population by Regency/City Administration 2014-2018

\begin{tabular}{|c|c|c|c|c|c|c|}
\hline \multirow[t]{2}{*}{ NO } & \multirow[t]{2}{*}{ DESCRIPTION } & \multicolumn{5}{|c|}{ NUMBER OF THE POOR POPULATION (000/Person) } \\
\hline & & 2014 & 2015 & 2016 & 2017 & 2018 \\
\hline 1 & $\begin{array}{lr}\text { Thousand } & \text { Islands } \\
\text { (officially } & \text { Kepulauan } \\
\text { Seribu) } & \end{array}$ & 2.7 & 2.65 & 2.96 & 3.09 & 2.88 \\
\hline 2 & South Jakarta & 80.8 & 74.46 & 71.96 & 69.82 & 63.38 \\
\hline 3 & East Jakarta & 96.5 & 91.44 & 91.37 & 95.67 & 91.38 \\
\hline 4 & Central Jakarta & 37.7 & 38.01 & 35.82 & 34.83 & 33.19 \\
\hline 5 & West Jakarta & 90.9 & 89.39 & 84.08 & 86.96 & 86.42 \\
\hline 6 & North Jakarta & 104.2 & 102.97 & 98.11 & 99.31 & 95.86 \\
\hline TO' & L DKI JAKARTA & 412.8 & 398.92 & 384.30 & 389.69 & 373.12 \\
\hline
\end{tabular}

Source: North Jakarta City in Figures,2019

Based on Table 1. The highest number of poor people is in North Jakarta City and the lowest is in the Thousand Islands. The number of poor people in 2018 are: (1) Thousand Islands 2,88 thousand people, (2) Central Jakarta 33,19 thousand people, (3) South Jakarta 63,38 thousand people, (4) West Jakarta 86,42 thousand people, (5) East Jakarta 91,38 thousand people and (6) North Jakarta 95,86 thousand people. 
Table 2.Percentage of Poor Population by Regency/City Administration 2014-2018

\begin{tabular}{|c|c|c|c|c|c|c|}
\hline \multirow[t]{2}{*}{ NO } & \multirow[t]{2}{*}{ DESCRIPTION } & \multicolumn{5}{|c|}{ NUMBER OF POOR POPULATION (\%) } \\
\hline & & 2014 & 2015 & 2016 & 2017 & 2018 \\
\hline 1 & $\begin{array}{l}\text { Thousand } \\
\text { (officially } \\
\text { Seribu) }\end{array}$ & 11.56 & 11.40 & 12.58 & 12.98 & 11.98 \\
\hline 2 & South Jakarta & 3.72 & 3.41 & 3.27 & 3.14 & 2.83 \\
\hline 3 & East Jakarta & 3.43 & 3.24 & 3.19 & 3.31 & 3.14 \\
\hline 4 & Central Jakarta & 4.12 & 4.16 & 3.91 & 3.78 & 3.59 \\
\hline 5 & West Jakarta & 3.72 & 3.64 & 3.38 & 3.45 & 3.39 \\
\hline 6 & North Jakarta & 6.00 & 5.91 & 5.57 & 5.59 & 5.35 \\
\hline $\mathbf{T O}^{\prime}$ & AL DKI JAKARTA & 4.09 & 3.93 & 3.75 & 3.77 & 3.57 \\
\hline
\end{tabular}

Source: North Jakarta City in Figures,2019

Based on Table 2. The percentage of poor people in DKI Jakarta in 2014 reached 4,09 percent, which includes 412,8 thousand people. The number of poor people in North Jakarta City, increased from 2016 to 2017 by 0.03 percent compared to 2018, the percentage of poor people decreased by 0,24 percent. This means that a successful poverty program is the result of good government performance, between the Central Government, DKI Jakarta Provincial Government and North Jakarta City Government.

Table 3. North Jakarta City Government Performance

\begin{tabular}{lllllll}
\hline \multirow{2}{*}{ NO } & \multirow{2}{*}{ DESCRIPTION } & \multicolumn{7}{c}{ REALIZATION (\%) } \\
\cline { 3 - 7 } & & 2013 & 2014 & 2015 & 2016 & 2017 \\
\hline 1 & Inflation Rate & 5.82 & 5.79 & 5.59 & 4.62 & 3.62 \\
2 & Unemployment Rate & 9.67 & 8.88 & 7.11 & 6.12 & 7.67 \\
$\mathbf{3}$ & Poverty level & $\mathbf{5 . 3 0}$ & $\mathbf{6 . 0 0}$ & $\mathbf{5 . 9 1}$ & $\mathbf{5 . 5 7}$ & $\mathbf{5 . 5 9}$ \\
4 & Economic growth & 5.82 & 5.79 & 5.59 & 4.62 & 3.62 \\
\hline
\end{tabular}

Source: North Jakarta City in Figures, 2018

Based on Table 3. The performance of the North Jakarta City Government has been good, namely (1) The inflation rate has decreased by $3.62 \%$, (2) Unemployment has increased by $7.67 \%$, (3) the poverty rate has decreased by $5.59 \%$ and (4) Economic growth has been $3.62 \%$. According to Fajri Ananda (2019), in the constellation of change, the role of the government will be to function more as a facilitator and quality assurance for the services to be performed. With fewer functions, of course, government organizations will experience squizzing (shrink) and some services will already be digital-based (faster and accessible).

Government work culture is increasingly being discussed along with the challenges of the industrial revolution 4.0 which demands a change in the quality of human resources. Law Number 5 of 2014 concerning State Civil Apparatus, regulate and organize the work culture of the government in order to support the implementation of an effective government system, efficient, and fair. One interesting material is the idea of implementing merit systems. The success of a job starts from values and behavior including customs, religion, norm, rules in organization that become a habit and are called culture. In this case, culture is associated with quality or work quality, called work culture. 


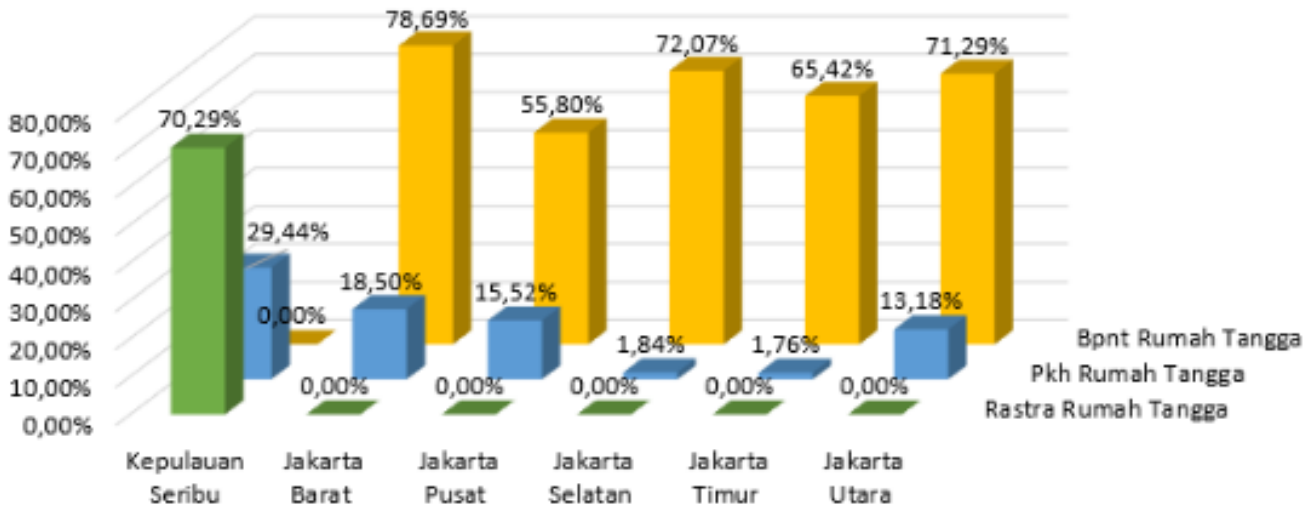

Figure 2. Percentage of Number of Beneficiary Families to Number of Poor Families/Households as of June 2018 DKI Jakarta

Based on Figure 2, Percentage of Number of Beneficiary Families to Number of Poor Families/Households as of June 2018 In DKI Jakarta, the poverty alleviation program is adjusted to the target for which assistance will be provided such as: BPNT, PKH, and Rastra given to households and the recipients are referred to as Beneficiary Families (KPM). Based on data from the DKI Jakarta Social Service, the number of beneficiary families as of June 2018 was 244,036 households consisting of recipients of PKH, BPNT, and Rastra assistance.

According to Soekidjo (2003: 2), an organization must be supported by competent human resources because human resources play a very important role in running a business or activity within the organization. There are factors that can cause employee performance to increase or decrease. Negative factors that cause employee performance to decline such as: a lot of pressure, loss of employee's desire to excel, circumstances in the work environment and no role model or reference in achievement. Other factors that can improve employee performance are influenced by government leadership, motivation, and organizational culture.

Djatmiko (2005: 47), suggests that leadership is a process between relationships or interactions between leaders, followers and the situation. Leadership must involve other people, subordinates or followers. Furthermore, according to Wahjosumidjo (1987), leadership is something that is attached to a leader in the form of certain traits such as personality, ability, and ability, leadership as a series of leaders activities who do not can be separated from the position and style or behavior of the leader itself.

Kinicki \& Kreitner (in Koesmono, 2013:57) stated that organizational culture is "is the set of shared, taken for granted implicit assumption that the group holds and determines how it perceives, thinks about, and reacts to its various environment". Meanwhile, according to Robbins, the function of organizational culture is to differentiate between one organization and another, build a sense of identity for members, facilitate the growth of commitment and increase the stability of the social system as a social glue towards organizational integrity. The characteristics of organizational culture are individual initiatives, tolerance for risky actions, direction, integration, management support, control, identity, reward systems, tolerance for conflict and communication patterns that are carried out in an organization (Umam, 2010: 135-136).

Performance according to Simamora in Mangkunegara (2009), is the results achieved by the individual in carrying out the tasks that have been assigned to him, both in terms of quality and quantity based on predetermined work standards. Performance in the organization is the answer to the success or failure of the organizational goals that have been set. Wirawan (2009:5), states that performance is the output produced by the functions or indicators of a job or a profession within a certain time. 
Mangkunegara (2000:67) states that performance is the result of work in quality and quantity achieved by an employee in carrying out his duties in accordance with the responsibilities given to him.

The poor quality and expertise of ASN has an impact on poor ASN performance, exacerbated by the existence of an organizational culture that does not pay attention to employee job satisfaction, as well as a lack of motivation from the leadership to encourage good performance. Generally, this condition is caused by a lack of job satisfaction owned by employees so that it worsens the performance of employees. The leadership applied is one of the factors that can cause such conditions.

\section{Methodology}

This researcher uses qualitative methods and quantitative with a total of 95 informants. This research was conducted using a mix method research method. Cresswell $(2010 ; 5)$ stated that mix method research method is a research approach that combines or combines quantitative and qualitative research. Quantitative analysis is descriptive statistics to describe the characteristics of respondents, descriptions of research variables and test hypotheses. While quantitative analysis by describing each research variable and discussing the relationship between variables to then be compared with the results of previous studies.

\section{Results and Discussion}

The North Jakarta area is part of the Special Capital Region of Jakarta. In the 17th century this area had become the center of the growth of the City of Batavia, with a location at the mouth of the Ciliwung river in the Angke area. At that time, those area was the Port of Tarumanegara Kingdom under the leadership of King Purnawarman. How important the North Jakarta area was at that time can be seen from the alternation of struggles between various parties, whose remains can be found in several places in North Jakarta, like the Tugu Village, Fish Market and so on.

The principle of deconcentration outlined by the governor in the formation of administrative cities provides boundaries of authority and responsibility to the Mayor in three affirmations, namely:

1) Administrative Technical, namely every task related to technical aspects.

2) Operational Technical, namely determining the policy for the implementation of tasks (Policy Executing, not Policy Making)

3) Territorial Coordinator is the leader of the coordination of all potential actions in the local area.

Law no. 11/1990 stipulates that the DKI Jakarta area is divided into five permanent municipal areas without being equipped with a Level II DPRD. Thus, the positions of the Mayor, Camat (Subdistrict Head), and Lurah (Village Head) in DKI Jakarta are merely assistants and tools for the implementation of the Governor of $\mathrm{KDH}$. Based on the results of statistical analysis in Table 4. shows the value of $\mathrm{N}$ or the amount of data studied amounted to 95 samples. The performance of the Poverty Reduction Program has a total average (mean) of 40.28 or 4.028 with a variance of 22,099 and a standard deviation of 4,700 . 


\section{Table 4. Descriptive Statistical Test Results X1, X2, X3 and Y}

\begin{tabular}{|c|c|c|c|c|c|c|c|c|}
\hline \multicolumn{9}{|c|}{ Descriptive Statistics } \\
\hline & $\begin{array}{l}\mathrm{N} \\
\text { Statistics }\end{array}$ & $\begin{array}{l}\text { Range } \\
\text { Statistics }\end{array}$ & $\begin{array}{l}\text { Minimum } \\
\text { Statistics }\end{array}$ & $\begin{array}{l}\text { Maximum } \\
\text { Statistics }\end{array}$ & $\begin{array}{l}\text { mean } \\
\text { Statistics }\end{array}$ & $\begin{array}{l}\text { Std. } \\
\text { Error }\end{array}$ & $\begin{array}{l}\text { Std. } \\
\text { Deviation } \\
\text { Statistics }\end{array}$ & $\begin{array}{l}\text { Variance } \\
\text { Statistics }\end{array}$ \\
\hline$\overline{\text { TOTAL X1 }}$ & 95 & 10 & 34 & 44 & 39.61 & 200 & 1,953 & 3.815 \\
\hline TOTAL X2 & 95 & 16 & 31 & 47 & 40.58 & ,353 & 3,441 & 11,842 \\
\hline TOTAL X3 & 95 & 16 & 31 & 47 & 40.32 & ,343 & 3,343 & 11.176 \\
\hline TOTALLY & 95 & 19.00 & 30.00 & 49.00 & 40.2842 & ,48231 & 4.70098 & 22,099 \\
\hline $\begin{array}{ll}\text { Valid } & \mathrm{N} \\
\text { (listwise) } & \end{array}$ & 95 & & & & & & & \\
\hline
\end{tabular}

Source: SPSS 25 output (processed data, 2020)

Based on the results of statistical analysis in Table 4 that shows the value of $\mathrm{N}$ or the amount of data studied amounted to 95 samples. Leadership variable has an average (39.61 or 3.961), Motivation has an average (40.58 or 4.058), Work culture has an average (40.32 or 4.032) and Increased poverty has an average (40, 28 or 4.028 with a standard deviation of each variable Leadership (1.963), Motivation (3.441), Work Culture (3.343) and Poverty Reduction Program Performance (4.700).

Table 5. Test of Validity and Reliability of Poverty Reduction Program Performance Levels $(\mathrm{Y})(\mathrm{n}=\mathbf{9 5}, \mathbf{= 1 0 \%}, \mathrm{df}=\mathbf{9 3})$

\begin{tabular}{|c|c|c|c|c|c|c|c|c|c|}
\hline \multirow[t]{2}{*}{ Question } & \multirow{2}{*}{$\begin{array}{l}\mathbf{r} \\
\text { statistic }\end{array}$} & \multirow[t]{2}{*}{$r$ table } & \multicolumn{2}{|l|}{ Validity } & \multirow[t]{2}{*}{ cronbach } & \multicolumn{4}{|l|}{ Reliability } \\
\hline & & & $\begin{array}{l}r \text { statistic } \\
\text { table }\end{array}$ & $>\mathbf{r}$ & & $\begin{array}{l}\text { cronbach } \\
\text { table }\end{array}$ & $\alpha$ & $>$ & $\mathbf{r}$ \\
\hline 1 & 0.509 & \multirow{10}{*}{0.1698} & \multirow{10}{*}{ Valid } & & \multirow{10}{*}{0.739} & \multirow{10}{*}{ Reliable } & & & \\
\hline 2 & 0.629 & & & & & & & & \\
\hline 3 & 0.488 & & & & & & & & \\
\hline 4 & 0.573 & & & & & & & & \\
\hline 5 & 0.593 & & & & & & & & \\
\hline 6 & 0.448 & & & & & & & & \\
\hline 7 & 0.674 & & & & & & & & \\
\hline 8 & 0.775 & & & & & & & & \\
\hline 9 & 0.519 & & & & & & & & \\
\hline 10 & 0.377 & & & & & & & & \\
\hline
\end{tabular}

From the results of the validity test in Table 5, it can be seen that the results are quite good and respondents agree that the reduction in the level of performance of the poverty reduction program is one way to measure the performance of regional leaders in, increase motivation, strengthen organizational culture, in Poverty Reduction. The statement with the highest Validity value is the eighth statement, indicators Interior and exterior design, the seven indicators Physical equipment and second Process and resource output. While the lowest validity value is the statement of the ten indicators of the ability to complete tasks well with a validity value of 0,377 .

Based on the results of the above calculations, the four hypotheses can be described in Table 6 . 
Table 6. Statistic Test Calculation of Variable X Against Y

\begin{tabular}{|c|c|c|c|c|c|c|}
\hline No & Hypothesis & Sig & $\alpha$ & $\mathbf{t}$ & $\mathbf{F}$ & $\begin{array}{c}\text { Accepted/Rejected } \\
\text { Hypothesis }_{\text {s }}\end{array}$ \\
\hline 1 & $\begin{array}{l}\text { Leadership affects Performance of the } \\
\text { Poverty Reduction Program in the } \\
\text { Administrative City of North Jakarta. }\end{array}$ & 0.000 & 0.05 & 15,203 & - & $\begin{array}{l}\text { Hypothesis } \\
\text { accepted }\end{array}$ \\
\hline 2 & $\begin{array}{l}\text { Motivation affects Performance of the } \\
\text { Poverty Reduction Program in the } \\
\text { Administrative City of North Jakarta. }\end{array}$ & 0.000 & 0.05 & 93.731 & - & $\begin{array}{l}\text { Hypothesis } \\
\text { accepted }\end{array}$ \\
\hline 3 & $\begin{array}{l}\text { Work culture affects Performance of the } \\
\text { Poverty Reduction Program in the } \\
\text { Administrative City of North Jakarta. }\end{array}$ & 0.000 & 0.05 & 9,424 & 88.811 & $\begin{array}{l}\text { Hypothesis } \\
\text { accepted }\end{array}$ \\
\hline 4 & $\begin{array}{l}\text { Leadership, Motivation and Work Culture } \\
\text { together influence the Performance of the } \\
\text { Poverty Reduction Program in the } \\
\text { Administrative City of North Jakarta. }\end{array}$ & 0.750 & 0.05 & 0.319 & 30,835 & $\begin{array}{l}\text { Hypothesis } \\
\text { accepted }\end{array}$ \\
\hline
\end{tabular}

Source: SPSS 25 output (processed data, 2020)

\section{Influence of Leadership on Poverty Reduction Program Performance in North Jakarta Administrative City.}

The results of the statistical test are quite good and respondents agree that Leadership (X1) can affect the Performance of the Poverty Reduction Program in North Jakarta Administrative City (Y). The highest validity is (1) the eighth statement, the indicator of Researching problems that occur (0.987) on the Participatory Dimension, (2) the fourth Completing the task on time (0.369) on the Effectiveness dimension, and (3) the tenth indicator of Completing the task according to the target $(0.327)$ on the dimensions of delegation of authority. This means that these indicators have a dominant influence on the decline in the level of performance of the Poverty Reduction Program (Y).

Leadership has an effect of $14.1 \%$ and the remaining $85.9 \%$ is influenced by other variables which not examined. Leadership has a small effect, this is supported by the value of the statement with the lowest validity value is the statement of the seven indicators. Solving the problem correctly with a validity value of 0.189 . This means that special attention is needed on the indicators of Solving problems correctly, indications of the problem so far in solving problems that are not in the right strategy/way or even not in accordance with the target/problem. So that, it takes the right strategy/way to solve the problem, different problems, different approaches and solutions, with the right problem solving, the right strategy or method will be obtained as well.

According to Wasistiono (2019), the authority of the mayor as the PPK (Employee Guidance Officer) has the full right to appoint and dismiss officials without intervention from anywhere, except from the president, because mayors and regents are extensions of the president. Indonesia's system of government is decentralized not stratified. "The governor is not the superior of the mayor and the regent, only the coordination and coordination are not binding but only as a reminder and inform, as well as the minister not from the superiors of the mayor/regent, the compatibility of chemistry in the ASN Law, there are two stages. The first stage is completely objective, the second stage is completely subjective consideration(https://www.pikiran-rakyat.com/bandung-raya/pr-01319003/sidang-gugatan-terhadapwalikota-bandung-ini-penjelasan-pakar-pemerintahan).

These results are reinforced by the location of the pilot project for poverty alleviation in DKI Jakarta, which is located in Kalibaru Village, Cilincing District, North Jakarta. The reason for choosing the pilot project was the result of a regional working meeting (RAKERDA) with the DKI Jakarta poverty reduction coordination team (TKPK), consisting of: NGOs, academics, and entrepreneurs. 
Kalibaru was chosen because the area has the highest poverty rate with complex problems but the village management is very cooperative in DKI Jakarta. This poverty alleviation program began with the construction of the north coast sea wall in the Kalibaru area in mid-2018.

Leadership (X1) needs to be considered by the Regional Government because Leadership (X1) linking policy objectives and their realization with the results of government activities. The results of Dwi's research (2017), state that the role of the leader is very influential on the creation of community participation in implementing poverty alleviation programs in the village.

Based on these problems, the efforts that must be made by the North Jakarta City Government are: the mayor as the leader of the North Jakarta Administrative City cooperates with multi stakeholders in alleviating poverty in the area, both with inter-regional cooperation (KAD) and private government cooperation (KPS). This is reinforced by Feith (1962), that the solidarity maker type of leadership uses the power of the people and the administrator type who overcomes poverty through administration or policy.

\section{Motivation Against Poverty Reduction Program Performance in North Jakarta Administrative City.}

The results of the statistical test are quite good and respondents agree that motivation (X2) can affect the performance of the Poverty Reduction Program in North Jakarta Administrative City (Y). Motivation has an effect of $50.2 \%$ on the poverty level, this is supported by the statement with the highest Validity value, namely (1) the statement of the eight Authoritative indicators (0.608) on the dimension of the need for power or work authority, (2) the four indicators of Desire to take responsibility (0.606). ) on the dimension of Needs in achieving success and, (3) the three indicators of Desire to obtain performance feedback (0.586) on the dimension of Needs in achieving success. This means that these indicators have a dominant influence on the decline in the level of performance of the Poverty Reduction Program (Y). While the lowest Validity value of the first statement of the Award indicator with a validity value of 0.182 . This means that special attention is needed on the Receive indicator.

This is supported by the opinion of Wibowo, et al (2011), that motivation is the main way to increase the success of poverty alleviation programs, namely by changing the lives of communities by utilizing their collective abilities. Collaborating with others to improve the quality of life in the form of poverty alleviation requires special skills such as the ability to cooperate, prosocial, group dynamics, leadership, conflict resolution between groups and within their own group.

\section{Work Culture on Poverty Reduction Program Performance in North Jakarta Administrative City.}

The results of the statistical test are quite good and respondents agree that Work Culture (X3) can affect the Decrease in Poverty Reduction Program Performance Levels (Y) in North Jakarta Administrative City, the statement with the highest Validity value is (1) the fourth statement, Organizational expectations of employees (0.627) on the Attention to detail dimension, (2) the eight work activity indicators $(0.580)$ on the team-oriented dimension, and (3) the third statement Carefully at work $(0.544)$ on the attention to detail dimension. This means that these indicators have a dominant influence on the decline in the level of performance of the Poverty Reduction Program (Y).

Work culture has an effect of $48.8 \%$, the remaining $51.2 \%$ is influenced by other variables which not examined in this study. One of the things that affect it is the lowest Validity value is statement six, the indicator of the center of attention of engineering and process management (0.149). This means that special attention should be paid to the indicators of technical and process management attention centers. With the attention of management techniques and processes will greatly help strengthen the work culture

The Influence of Leadership, Motivation and Work Culture on the Performance of Poverty Reduction Program in the Administrative City of North 
in reducing poverty levels. Techniques related to how to anticipate and raise the spirit of work culture supported by good and optimal processes in strengthening work culture.

This is supported by Ndraha (2003:111) that the role is a dynamic aspect of the institution or the role of representing the institutional order of an institution. In addition, being lazy to work is a part of the majority of people's culture, namely wanting more things or maximum results with little effort. The fact is when someone wants maximum results, it must be included with maximum effort as well. And vice versa, there will be no optimal results, satisfying with a little effort.

Socio-cultural and religious poverty will trigger high rates of crime and radicalism. So to overcome and avoid crime and radicalism, it must be accompanied by a good work culture, and firm and right on target. The government's work culture that empowers the community will help the Poverty Reduction Program Performance, especially in the North Jakarta Administrative City.

With regard to Work Culture (X3), the North Jakarta Administration City Government needs to pay attention to the right balance and pattern of community empowerment according to the situation, conditions and needs of the community. Thus, it is hoped that the work culture will affect the Performance of the Poverty Reduction Program in the North Jakarta Administrative City.

\section{Leadership, Motivation and Work Culture on Poverty Reduction Program Performance in North Jakarta Administrative City.}

The results of the statistical test were quite good and the respondents agreed to optimize the Poverty Reduction Program Performance Level (Y) in North Jakarta Administrative City. The statement with the highest Validity value is the eighth statement, an indicator of interior and exterior design (0.775), the seven indicators of physical equipment (0.674) and the second Process and resource output (0.629). This means that these indicators have a dominant influence on the decline in the level of performance of the Poverty Reduction Program (Y). While the lowest validity value is the statement of the ten indicators of the ability to complete the task well with a validity value of $(0.377)$.

Leadership $\left(\mathrm{X}_{1}\right)$, Motivation $\left(\mathrm{X}_{2}\right)$, and Work Culture $\left(\mathrm{X}_{3}\right)$, which simultaneously have an effect of $50.4 \%$ and the remaining $49.6 \%$ is influenced by other variables that not examined. This is supported by the results of field observations that with good leadership, motivation and work culture will reduce poverty levels in the North Jakarta Administrative City.

According to Dwi (2017), the role of the leader is very influential on the creation of community participation in implementing poverty alleviation programs in the village. Supported by motivation as the main way to increase the success of poverty alleviation programs, namely by changing the lives of communities by utilizing their collective abilities (Wibowo, et al; 2011). Furthermore, Ndraha (2003:111), stated that the role is a dynamic aspect of the institution or the role of representing the institutional order of an institution.

Based on the result above, it is concluded that leadership, motivation and work culture simultaneously play a role in alleviating poverty, especially in the North Jakarta Administrative City. Supported by strengthening indicators of ability to complete tasks well, so that poverty alleviation programs can run optimally.

\section{Conclusion}

1. There is an influence of leadership on the performance of the Poverty Reduction Program in North Jakarta City Administration by $14.1 \%$, the rest (85.9\%) is influenced by other variables which not examined in this study. This is because the leadership of the government has not been maximized so 
that the impact on the leadership under it has not been felt, and the good governance of the North Jakarta City government has not been maximized as well. Supported by the low statement of the seven indicators Solving the problem correctly with a validity value of 0.189 . So it is necessary for a leader to develop a strategy in solving a problem precisely, because each problem has a uniqueness, and a different approach in solving it. So the researcher concludes the importance of transformational leadership which is supported by managerial progress, education and commitment.

2. There is an influence of motivation on the performance of the Poverty Reduction Program in North Jakarta City Administration of $50.2 \%$, the rest (49.8\%) is influenced by other variables which not examined in this study. This is due to the low motivation of employees in improving performance through improving the quality of human resources formally and informally, so that the North Jakarta City Administration does not yet have competent apparatus resources in their fields. It is supported by the low statement of the first award indicator with a validity value of 0.182 . So it is necessary for leaders to apply rewards and punishments in increasing motivation, especially for implementing poverty programs, as well as to the community in the form of home industry facilitation or an integrated tourist area is created which has an impact on increasing people's income, so that the poverty rate in North Jakarta decreases and can even be resolved into a prosperous and prosperous society. So the researcher concludes the importance of motivation, both internal and external, supported by rewards and punishments.

3. There is an influence of Work Culture on Poverty Reduction Program Performance in North Jakarta City Administration by $48.8 \%$, the rest $(51.2 \%)$ is influenced by other variables which not examined in this study. This is due to the weak work culture which has an impact on the low performance of North Jakarta Administrative City ASN so that it has an impact on achieving the target realization of the work program. Supported by the low statement six, the indicator of the center of attention of engineering and process management (0.149). This concludes the importance of a work culture supported by organizational commitment, strategy, management techniques and processes. With the commitment, the work culture will be stronger so that it will have a positive impact on the implementation of the program to be more optimal.

4. There is a simultaneous influence of leadership, motivation and work culture on the performance of the Poverty Reduction Program in the Administrative City of North Jakarta by $50.4 \%$, the rest $(49.6 \%)$ is influenced by other variables which not examined in this study. This is because the poverty rate is still high in the North Jakarta Administrative City, and the North Jakarta Administrative City Administration is not yet optimal in increasing motivation and work culture so that employee performance is efficient and effective with the support of professional, responsible, honest, and fair employees. Supported by the low statement of the ten indicators of Ability to complete tasks well with a validity value of (0.377). This concludes the importance of Leadership, Motivation and work culture simultaneously in reducing poverty levels are supported by management, commitment, skills, strategies, and human resources so that poverty reduction programs can run optimally and optimally.

5. From the results of the study, there are theoretical implications for the magnitude of the influence of leadership, motivation, and work culture together on the performance of the Poverty Reduction Program in the Administrative City of North Jakarta. Supported by best practices, methods and data collection techniques used (questionnaires, documentation and interviews), it is very helpful for researchers to explore information which is expected to strengthen the theoretical implications.

\section{Suggestion}

To support the Performance of the Poverty Reduction Program in North Jakarta City, based on the results of the study, the following must be carried out: 
1. It is hoped that the leadership can overcome poverty through community empowerment based on local potential, strengthened by good communication, and coaching for the creation of community participation in implementing bottom-up Poverty Reduction programs. Also supported by firm leadership in building multi-stakeholder synergy, especially poverty reduction programs in North Jakarta City.

2. It is hoped that motivation is created through rewards and punishments, so that it becomes a trigger to undergo and succeed in the poverty alleviation program. By creating internal and external motivation, it is hoped that it will strengthen good cooperation between the North Jakarta city government and the surrounding community, especially the community in the DKI Jakarta pilot project location in North Jakarta City.

3. It is expected that a good work culture can strengthen organizational management supported by commitment, management and the availability of potential human resources, according to needs and placements in accordance with their fields. In anticipating the limitations of human resources, it can be implemented through empowerment through formal and non-formal education.

4. It is hoped that leadership, motivation, and work culture simultaneously through good management, commitment, resources (natural, human, and artificial), supported by rewards and punishments can reduce the level of poverty in the city of North Jakarta. So that the poverty program that was carried out resulted in success and brought the City of North Jakarta as a pilot for poverty alleviation in DKI Jakarta and can be applied in other areas.

5. It is hoped that the methods and techniques used can be a reference for further researchers, in digging for further information so that the research results can prove the superiority of the methods used.

\section{References}

Agus Purwanto, Erwan dan Dyah Ratih Sulistyastuti. 2011. Metode Penelitian Kuantitatif untuk Administrasi Publik dan Masalah-masalah Sosial. Yogyakarta: Gava Media.

Algensindo Keban, Yeremias T.2008. Enam Dimensi Strategis Administrasi Publik. Yogyakarta: Gava Media

Arikunto, Suharmi. 2006. Prosedur Penelitian Suatu Pendekatan Praktik. Jakarta: PT.Rieneka Cipta

Asnawi \& Masyhuri. 2011. Metodologi Riset Manajemen Pemasaran. Malang: UIN Maliki Press

Bambang Prasetyo dan Lina Miftahul Jannah. 2007. Metode Penelitian Kuantitatif: Teori dan Aplikasi, Jakarta: PT Raja Grafindo Persada

Chaudhuri, Shubham.2003. Assessing Vulnerability to Poverty: Concepts, Empirical Methods and Illustrative Examples. Department of Economics Columbia University.

Dubrin Andrew J., 2005. Leadership (Terjemahan), Edisi Kedua, Prenada Media, Jakarta.

Edy Sutrisno. 2009. Manajemen Sumber Daya Manusia. Jakarta: Kencana Prenada Group.

Hofstede, Geert.1991. Cultures and Organizations, Intercultural Cooperation and Its Important for Survival., London; Harper Collin Business.

Johnson, B. \& Christensen, L.2012.Educational Research 4th Ed.: Quantitative, qualitative, and mixmethods approaches. California: SAGE Publication 
Kast, Fremont E. \& Rosenzweig.1970. Organisasi dan Manajemen. Jakarta: Bina Aksara

Kreitner, Robert, Kinicki, Angelo.1995. Organizational Behavior. Third Edition, Printed in The United State of America: Richard D. Irwin Inc.

Kreitner, R., \& Kinicki, A. 2010. Organizational Behavior (9th Ed.). New York: Mcgraw-Hill.

Munawaroh.2012. Panduan Memahami Metodologi Penelitian. Cetakan Pertama. PT.Intimedia.

Nimran Umar.2004. Perilaku Organisasi, Cetakan Ketiga. Surabaya; CV. Citra Media

Rivai, Veithzal dan Ella Djauhari Sagala. 2013.Manajemen Sumber Daya Manusia Untuk Perusahaan. Jakarta; Rajawali Pers

Rivai, Veithzal. 2004. Kiat Memimpin dalam Abad ke-21. Jakarta; PT Raja Grafindo Persada

Rivai, Veithzal dan Deddy Mulyadi. 2012. Kepemimpinan dan Perilaku Organisasi Edisi Ketiga. Jakarta: PT. Rajagrafindo Persada.

Robbins P. Stephen.2001. Perilaku Organisasi. Ahli bahasa Tim Indeks.

Robbins, P. Stephen. 1994. Teori Organisasi strukturtur, desain \& Aplikasi. ARCAN: San Diego State University

Robbins,Stephen P.dan Timothy A.Judge.2008.Perilaku Organisasi. Edisi ke-12. Jakarta: Salemba Empat.

Sedarmayanti. 2009.Sumber Daya Manusia dan Produktivitas Kerja.Bandung; CV. Mandar Maju

Siagian Sondang P., 2002. Kiat Meningkatkan Produktivitas Kerja. Cetakan Pertama, PT. Rineka Cipta, Jakarta

Smircich, L. 1983. Concept of Culture and Organizational Analysis. Administrative Science Quarterly

Steers, Richard M.1985. Efektifitas Organisasi: Kaidah Perilaku. Cet. Kedua. Jakarta: Erlangga

Stoner, Freeman dan Gilbert.1995. Pengantar Bisnis.Yogyakarta; Graha Ilmu

Subino.1982. Bimbingan Skripsi. Bandung; ABA Yapari

Sugiyono. 2011.Metode Penelitian Kuntitatif kualitatif dan R \& D. Bandung;Alfabeta.

Sugiyono. 2008. Metode Penelitian Kuantitatif, Kualitatif, dan R\&D. Bandung: Alfabeta

Sugiyono. 2010. Metode Penelitian Pendidikan. Bandung: Alfabeta.

Sugiyono.2003. Metode Penelitian Bisnis Edisi 1. Bandung; Alfabeta

Sugiyono. 2006.Metode Penelitian Kuantitatif, Kualitatif dan R \& D.Bandung:Alfabeta.

Suharto, Edi. 2009. Membangun Masyarakat Memberdayakan Rakyat. Bandung: Rafika Aditama

Sumarmi.2012. Pengembangan Wilayah Berkelanjutan.Malang; Aditya Media Publishing

Suyono, Haryono. 2006. Pemberdayaan Masyarakat. Jakarta: Khanata

Schreiber, A.D. 1989. Monocyte Fc gamma receptor recognition of cell bound and aggregated IgG. Blood; 44:1058-1065. 
Syafiie, Inu Kencana.2006. Ilmu administrasi publik. Jakarta: PT Asdi

Syafrudin, Ateng.2006. Kapita Selekta; Hakikat Otonomi dan Desentralisasi Dalam Pembangunan Daerah. Yogyakarta; Citra Media

Taliziduhu Ndraha.2003.Teori Budaya Organisasi. Cetakan Kedua.Jakarta : PT. Rineka Cipta

Todaro, Michael P. dan Smith, Stephen C.2004. Pembangunan Ekonomi di Dunia Ketiga (Jilid 1, Edisi Kedelapan). Jakarta: Erlangga.

Umam, Khaerul. 2010. Perilaku Organisasi. Bandung: Pustaka Setia.

Wirawan.2007. Budaya dan Iklim Organisasi. Jakarta: Salemba Empat

World Bank, Governance. 1993.The World Bank Experience: operations policy, Document, Final Draft

Yukl, Gary A.1989. Leadership in Organizations. 2nd Ed.New Jersey: Prentice-Hall International, Inc

Aan Hardiyana, Farina Helwiyan.2011. Pengaruh Kepemimpinan, Motivasi, dan Lingkungan Kerja Terhadap Kinerja Pegawai Badan Kepegawaian Pendidikan dan Pelatihan Kabupaten Bandung.Jurnal Vol. 5, No. 2

Anggraini, Neni.2011. Pengaruh Kemampuan Dan Motivasi Terhadap Kinerja Pegawai Pada Sekolah Tinggi Seni Indonesia (STSI) Bandung; Jurnal Penelitian Pendidikan Vol.12 No.2

Bhenyamin Hoessein. 2002.Kebijakan Desentralisasi.Jurnal Administrasi Negara Vol. II. No.02. Maret. 2002, hlm. 3 .

Ester Manik dan Dhea Perdana.2015. Pengaruh fungsi kepemimpinan, kompetensi dan budaya organisasi terhadap kinerja pegawai pada direktorat jenderal energi baru, terbarukan dan konservasi energi (DJEBTKE). Jurnal Ekonomi, Bisnis dan Enterepreneurship Vol 9/ STIE Pasundan, Bandung.

Ishan Krisna Saikia, dkk.2013. Good Governance and Human Rights: International and National Persepective, International jurnal of Advancements in Research and Technology, Volume 2, Issue 7, July-2013.

Marpaung, Marudu. 2014. Pengaruh Kepemimpinan dan Team Work Terhadap Kinerja Karyawan di Koperasi Sekjen Kemdikbud Senayan Jakarta. Jurnal Ilmiah WIDYA Vol.2 Nomor.1

Meri Yarni dan Latifah Amir.2014. Penguatan Tata Kelola Pemerintahan yang baik dalam Pembentukan Peraturan Perundang-Undangan Sebagai Pilar Penegakan Hak Asasi Manusia Di Indonesia:jurnal ilmu hukum

Nawawi, Juanda.2012. Membangun Kepercayaan Dalam Mewujudkan Good Governance; e-journal Universitas Hasanuddin

Sekaran, Uma dan Coral R. Snodgrass, 1986. A. Model for Examining Organizational Effectiveness Cross-Culturally, Advances in International Comparative Management, Vol 2.

Yuliana.2017. Pengaruh Kepemimpinan, Motivasi dan Budaya Organisasi Terhadap Kinerja Pegawai Pada Kantor Wilayah Kementerian Agama Propinsi Sulawesi Tenggara. Jurnal Pascasarjana Universitas Haluelo, Kendari.

Anonim.2018. Kota Jakarta Utara dalam Angka.2018.Jakarta; BPS

The Influence of Leadership, Motivation and Work Culture on the Performance of Poverty Reduction Program in the Administrative City of North 
Anonim.2017. Laporan Kinerja Instansi Pemerintah DKI Jakarta.2017.Jakarta; Pdf

BKKBN-Laporan Kinerja Presiden 4 Tahun.2018; Jakarta

Femtine Wirditiani.2008. Pengaruh Kepemimpinan, Pengelolaan Pengetahuan, Pengelolaan Sistem Kerja Terhadap Kinerja Operasional Departemen Radiologi RSUPN Dr Cipto Mangunkusumo Tahun 2008; Tesis

Goestyari Kurnia Amantha.2016. Analisis Budaya Kerja Dalam Menciptakan SDM yang berkualitas (Studi pada Biro Organisasi Sekda Provinsi Lampung).Tesis; UNLA

Hutauruk, Syarfi.2015. Pengaruh Gaya Kepemimpinan Tehadap Kinerja Pegawai Melalui motivasi kerja pada Dinas Kesehatan Pemerintahan Kota Sibolga. Tesis; Universitas Terbuka; Jakarta

Janjohono, Binawan Nur.2006. Pengaruh Motivasi Kerja Dan Budaya Organisasi Terhadap Kinerja Pegawai di Lingkungan Dinas Bina Marga Propinsi Jawa Tengah; Tesis; Universitas Muhammadiyah Surakarta

Sukmaniar.2007.Efektivitas Pemberdayaan Masyarakat Dalam Pengelolaan Program Pengembangan Kecamatan (PPK) Pasca Tsumani di Kecamatan Lhoknga Kabupaten Aceh Besar. Tesis; Magister Teknik Pembangunan Wilayah dan Kota: Universitas Diponegoro

Rani, Mariam.2009. Pengaruh Gaya Kepemimpinan dan Budaya Organisasi Terhadap Kinerja Karyawan melalui Kepuasan Kerja Karyawan sebagai variabel Interventing Studi pada Kantor Pusat PT. Asuransi Jasa Indonesia (Persero). Tesis. Semarang; UNDIP

Undang-Undang No. 5 Tahun 2014 Tentang Aparatur Sipil Negara (ASN)

Undang-Undang Nomor 23 Tahun 2014 Tentang Pemerintahan Daerah

Keputusan Menpan Nomor 25/Kep/M.Pan/4/2002 Tentang Pedoman Pengembangan Budaya Kerja Aparatur Negara

http://habibiarifin.blogspot.com , diakses tanggal 21 Mei 2019 jam 20:58 Wib

http://candrafajriananda.lecture.ub.ac.id/2019/02/budaya-kerja-pemerintahan/diakses pada 17 Mei 2019 jam 18:57 Wib

www.baldrige.nist.gov diakses tanggal 11 Mei 2019 jam 08:28 Wib

http://statistik.jakarta.go.id/realisasi-program-penanganan-kemiskinan-di-dki-jakarta/ diakses tanggal 25 Mei 219 Jam 10:24 Wib

https://www.beritajakarta.id/read/74960/pemprov-dki-gelar-rakerda-penanggulangan-kemiskinan diakses tanggal 20 Desember 2019 Jam 10:47 Wib

\section{Copyrights}

Copyright for this article is retained by the author(s), with first publication rights granted to the journal.

This is an open-access article distributed under the terms and conditions of the Creative Commons Attribution license (http://creativecommons.org/licenses/by/4.0/). 